\title{
RAY-FLORETLESS SUNFLOWER IN THE INTERSPECIFIC DERIVATIVES OF THE CROSS Helianthus annuus L. $\times$ H. divaricatus
}

Sujatha, M.

Directorate of Oilseeds Research, Rajendranagar, Hyderabad 500 030, India

Received: October 17, 2007

Accepted: August 10, 2008

SUMMARY

A novel variant devoid of rayflorets was identified in the interspecific derivatives of the cross between cultivated sunflower and $H$. divaricatus. The outermost whorl of the capitulum was comprised of modified disc florets which had longer petals than the regular disc florets and were hermaphrodite unlike the ray florets which are unisexual with non-functional stigmas. Inheritance studies indicated that the apetalous trait is under monogenic recessive gene control. Utility of the trait in physiological and breeding studies is under investigation.

\section{Key words: apetalous flowers, $\boldsymbol{H}$. divaricatus, interspecific hybridization, sunflower}

\section{INTRODUCTION}

Sunflower (Helianthus annuus L.) (Family: Asteraceae) is an important oilseed crop worldwide. Successful cultivation of the crop is limited by the vulnerability of the crop to several biotic stresses. In India, leaf spot caused by Alternaria helianthi is economically important. Sources of resistance to this pathogen have been identified in wild sunflowers (Morris et al., 1983; Sujatha et al., 1997). H. divaricatus, a diploid perennial is an important source of resistance to Alternaria leaf spot, downy mildew and Diaporthe helianthi (Sujatha et al., 1997; Korell et al., 1996). An introgressive breeding program has been initiated with the objective of transferring resistance to $A$. helianthi from this wild species to cultivated sunflower. The $\mathrm{F}_{1}$ hybrids were highly fertile with formation of 17 regular bivalents. The dominance of wild characters such as branching and pointed bracts was observed in the $\mathrm{F}_{1}$ and $\mathrm{BC}_{1}$ generations. At $\mathrm{BC}_{2}$, phenotypically superior plants were selected and interma-

* Corresponding author: Phone: 91-040-24015344; Fax: 91-040-24017969; e-mail:mulpurisujata@yahoo.com 
ted to avoid narrowing down the variability for the polygenically controlled trait such as Alternaria resistance.

\section{RESULTS AND DISCUSSION}

A novel flower variant without ray florets has been identified in the $\mathrm{BC}_{2} \mathrm{~F}_{8}$ generation of the derivatives of the cross involving cultivated sunflower and $\mathrm{H}$. divaricatus (Figure 1a). Such capitula can be called homogamous, eradiate, eliguliflorous or discoid heads. Selfing and sister-plant mating of this morphotype resulted in the development of a stable line bearing ligulate-less flowers. Sunflower, including wild sunflower species, possess an attractive inflorescence in the form of a composite head called the capitulum with two types of florets. The outermost whorl of florets is yellow in color and comprised of ray florets or ligulate flowers. These florets are unisexual, pistillate, but their stigmas are non-functional. The disc florets or tubular florets form the central disc. They are hermaphroditic and have bifid stigmas encased in a syngenesious anther column. The genus Helianthus comprises of 49 species and all the members of this genus have the same basic floral structure while variations are observed only with regard to the number of florets, color of ray flowers, color of stigmas, color of the disc but none are apetalous (Rogers et al., 1982).

Derivatives of a cross $H$. annuus $\times H$. divaricatus possessed a distinct plant type. The plants were late maturing, dwarf, with slender stems. Leaves and stems were smooth and non-pubescent. Leaves were thick and leathery with short petioles. Floral bracts were invariably pointed and the capitula were flat. The size of the flowers was normal and of the same size as that of flowers from sister lines with ray flowers. The outermost single layer had modified florets that were intermediate of the ray and disc florets. The corolla color was yellow similar to that of the ray florets but they were tubular and hermaphroditic as the disc florets (Figures $1 \mathrm{~b}$ and c). However, this modified layer of florets had slightly longer tubular florets than the regular disc florets.

The specific characteristics of this plant type are:

- plant height - $60.0 \mathrm{~cm}$; head diameter - $12.5 \mathrm{~cm}$;

- days to flowering - 58;

- days to maturity - 90;

- leaf margin - smooth;

- seed color - black;

- capitulum - only tubular disc florets;

- pollen color - yellow;

- oil content - 33.0\%;

- 100-seed weight - $4.8 \mathrm{~g}$ and

- seed filling frequency - $92 \%$

There were no significant differences in the quantitative and qualitative traits between the variant and its counterpart with petals except for the homogamous $v$ s heterogamous heads. The plants possessed field tolerance to A. helianthi. 

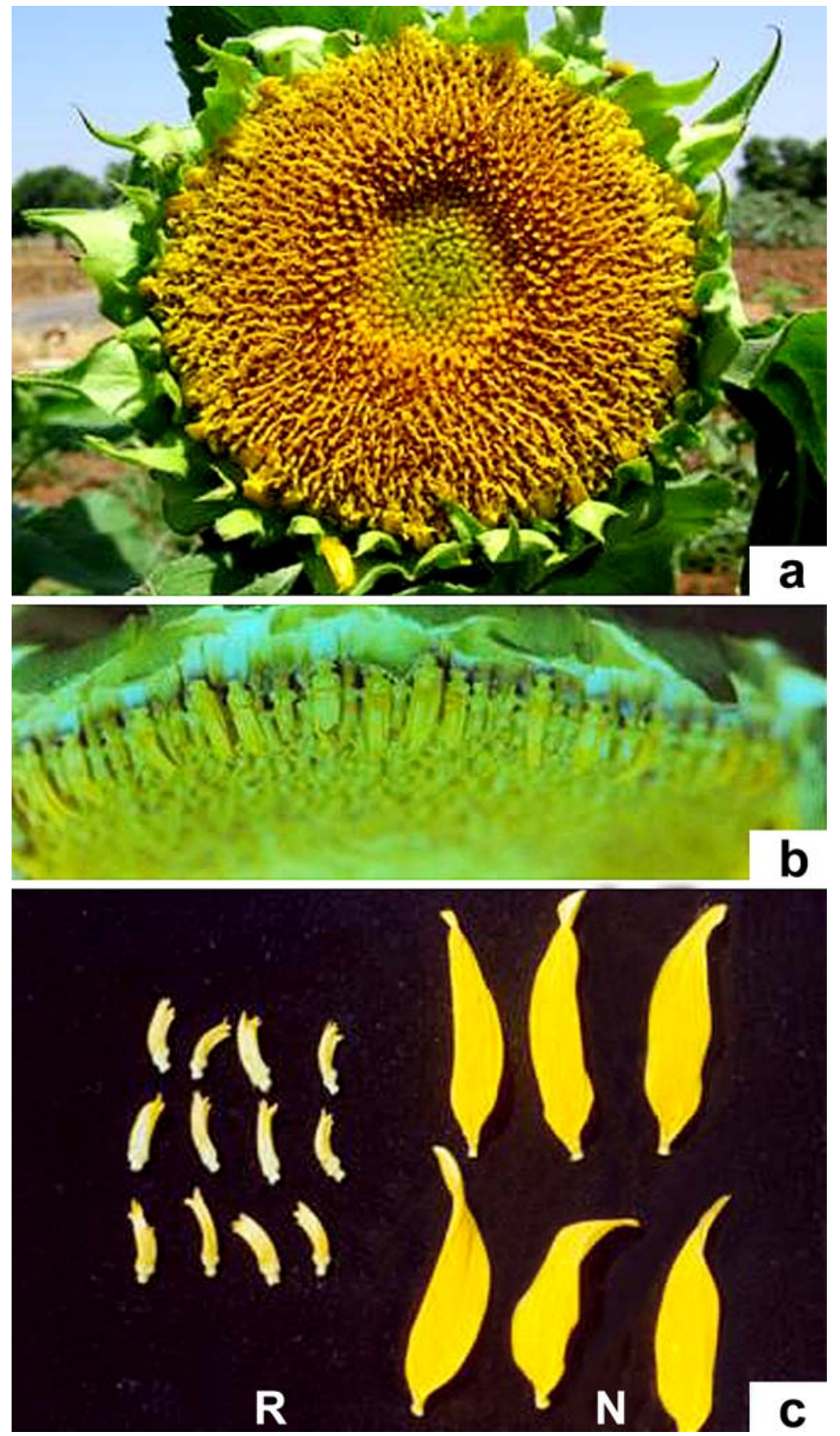

Figure 1: a) Ray-floretless flower in sunflower,

b) Outer whorl showing rudimentary tubular florets,

c) Florets in the variant and normal capitulum. 
This particular cross is of interest for sunflower breeding as it has resulted in other genetic variants such as plants producing white pollen and plants with Y-type branching bearing uniform-sized twin heads (Prabakaran and Sujatha, 2003). The white pollen trait is under the control of a monogenic recessive gene while the genetics of double-headed sunflower is yet to be understood. The genetics of ray florets absence in the genetic variant isolated from $H$. annuus $\times H$. divaricatus was determined and was found to be under monogenic recessive gene control. In Brassica, apetaly derived from different sources is controlled by one to four recessive genes and it is subjected to the influence of modifiers or controlled by epistatic interactions (Jiang and Becker, 2003). Apetalous trait has been reported in apple (Tobutt, 1994), linseed (Sorochinskaya and Galkin, 1972) and cucumber (Grimbly, 1980) as well, and it has been found to be controlled by a single recessive gene. In sunflower, the absence of ligulate flowers was controlled by three genes, $F d_{1}, F d_{2}$ and $\mathrm{Fd}_{3}$ (Škaloud and Kovačik, 1978) and the absence of tubular ray florets by a single recessive gene (Fick, 1976). Since the origin of the ligulate-less flowers in sunflower is different, the genetic control of this trait may not be the same and hence, detailed investigations are required for establishing its genetic control and its linkage relationship with other desirable attributes.

\section{CONCLUSION}

Ray florets have an important role in sunflower breeding particularly in hybrid seed production that depends on honeybees for pollination. Morphological modifications of the flower could lead to less attractiveness to honeybees and influence the foraging behavior of the insects. Sunflower was originally used for ornamental purpose and several ornamental sunflowers with varied petal colors had been bred. Notwithstanding the advantages with the yellow-colored petals, apetalous flowers are valued in several crop plants. Apetalous genotypes are of interest in Brassica breeding because of their more efficient photosynthesis and reallocation of the photosynthesized assimilates, drought endurance ability and lower probability of infection from Sclerotinia sclerotiorum distributed by petals (Chapman et al., 1984; Mendham et al., 1991). In sunflower, the brightly colored ray flowers are at the capitulum periphery for an extended period and reflect the photosynthetically active radiation. The other breeding objectives include drought tolerance and resistance to S. sclerotiorum and hence, it is worth investigating the potential of apetalous character in circumventing these problems in sunflower.

This study reveals that wild Helianthus species not only have valuable genes for the improvement of cultivated sunflower but also preserve large genetic variability in them that can be exploited for further improvement of this crop. Further studies on converting the trait to a suitable agronomic background and assessing its physiological efficiency and resistance to biotic and abiotic stresses are required. 


\title{
REFERENCES
}

Chapman, J.F., Daniels, R.W. and Scarisbrick, D.H., 1984. Field studies on ${ }^{14}$ C assimilate fixation and movement in oilseed rape (B. napus). J. Agric. Sci. Camb. 102: 23-31.

Fick, G.N., 1976. Genetics of floral color and morphology in sunflowers. J. Hered. 67: 227-230.

Grimbly, P.E., 1980. An apetalous male sterile mutant in cucumber. Plant Breed. Abst. 51: 11023.

Jiang, L. and Becker, H.C., 2003. Inheritance of apetalous flowers in a mutant of oilseed rape. Crop Sci. 43: 508-510.

Korell, M., Brahm, L., Friedt, W. and Horn, R., 1996. Interspecific and intergeneric hybridization in sunflower breeding. II. Specific uses of wild germplasm. Pl. Breed. Abst. 66: 10811091.

Mendham, N.J., Rao, M.S.S. and Buzza, G.C., 1991. The apetalous flower character as component of a high yielding ideotype. Proc. GCIRC $8^{\text {th }}$ International Rapeseed Congress, Saskatoon, Canada, pp. 596-600.

Morris, J.B., Yang, S.M. and Wilson, L., 1983. Reaction of Helianthus species to Alternaria helianthi. Plant Dis. 67: 539-540.

Prabakaran, A.J. and Sujatha, M., 2003. Identification of novel variants in interspecific derivatives of Helianthus divaricatus and cultivated sunflower. Helia 26(39): 167-170.

Rogers, C.E., Thompson, T.E. and Seiler, G.J., 1982. Sunflower species of the United States. pp. 41-43. Nat. Sunfl. Assoc., Fargo, North Dakota, USA.

Škaloud, V. and Kovačik, A., 1978. Survey on inheritance of sunflower characters which are conditioned by a small number of genes. Proc. of $8^{\text {th }}$ Int. Sunfl. Conf., Minneapolis, MN, July 23-27, 1978, pp. 490-496.

Sorochinskaya, M.A. and Galkin, F.M., 1972. Male sterility in linseed (Linum usitatissimum L.). Plant Breed. Abst. 46: 6418.

Sujatha, M., Prabakaran, A.J. and Chattopadhyay, C., 1997. Reaction of wild sunflowers and certain interspecific hybrids to Alternaria helianthi. Helia 20(27): 15-24.

Tobutt, K.R., 1994. Combining apetalous parthenocarpy with columnar growth habit in apple. Euphytica 77: 51-54.

\section{GIRASOL SIN FLORES LIGULADAS ENTRE LOS DERIVADOS DEL CRUZAMIENTO INTERESPECÍFICO Helianthus annuus L. $\times$ H. divaricatus}

\author{
RESUMEN
}

Se identificó una nueva variante sin flores liguladas entre los derivados del cruzamiento interespecífico entre girasol cultivado y $H$. divaricatus. El radio externo del capítulo estaba constituido por flores del disco modificadas de pétalos más largos que las flores del disco regulares y fueron hermafroditas al contrario de las flores del radio normales que son unisexuadas y presentan estigmas no funcionales. Estudios de herencia indicaron que el carácter a pétalo está bajo un control monogénico recesivo. La utilidad de este carácter en estudios fisiológicos y de mejoramiento está bajo investigación.

\section{TOURNESOL SANS FLEURONS LIGULÉS SUR LE CAPITULE CHEZ LES DÉRIVÉS INTERSPÉCIFIQUES DU CROISEMENT Helianthus annuus $\mathrm{L} . \times \mathrm{H}$. divaricatus}

\author{
RÉSUMÉ
}

Un nouveau variant sans fleurs ligulées a été identifié parmi les descendants interspécifiques du croisement entre le tournesol cultivé et $H$. divaricatus. 
La partie la plus externe du capitule est composée de fleurs tubules modifiées ayant des pétales plus grands que ceux des fleurs tubulées normales et sont hermaphrodites, alors que les fleurs ligulées normales ne le sont pas et ont un stigmate non fonctionnel. Des études d'hérédité montrent que le caractère apétale est sous contrôle monogénique récessif. L'utilité de ce caractère pour les etudes de physiologie et de génétique fait l'(objet de recherches. 